\title{
ADDENDUM
}

\section{Brain connectivity changes occurring following cognitive behavioural therapy for psychosis predict long-term recovery}

L Mason, E Peters, SC Williams and V Kumari

Translational Psychiatry (2017) 7, e1209; doi:10.1038/tp.2017.194; published online 15 August 2017

Addendum to: Translational Psychiatry (2017) 7, e1001; doi:10. 1038/tp.2016.263; published online 17 January 2017

After publication, the authors determined that regression tests are the appropriate post hoc tests for clarifying the direction of the three MANOVA results that found significant associations between functional connectivity changes and long-term clinical outcomes. In each of the three regression tests, greater increases in functional connectivity were associated with improved longterm clinical outcomes, as ascertained by positive beta weights for the following regressors: longitudinal positive psychotic symptoms $(\beta=0.157, t(14)=2.79 ; P=0.015)$, longitudinal affective symptoms $(\beta=0.187, t(14)=2.36 ; P=0.035)$ and subjective long- term recovery $(\beta=0.13, t(14)=2.56 ; P=0.024)$. These tests replace the correlation tests originally reported in the article.

(c) (i) This work is licensed under a Creative Commons Attribution 4.0 International License. The images or other third party material in this otherwise in the credit line; if the material is not included under the Creative Commons license, users will need to obtain permission from the license holder to reproduce the material. To view a copy of this license, visit http://creativecommons.org/licenses/ by/4.0/

(c) The Author(s) 2017 